\title{
Accuracy of three-dimensional surface model of bone derived from MRI
}

\author{
○正 笹川 圭右 (新潟大学) 渡辺 聡（新潟こばり病院）正 小林 公一（新潟大学） \\ 正 坂本 信（新潟大学）佐藤 卓（新潟こばり病院）古賀 良生（新潟こばり病院）
}

Keisuke SASAGAWA. NIIGATA University, 8050 Ikarashi-2no-cho, Niigata
Satoshi WATANABE. Niigata Kobari Hospital, 3-27-11 Kobari, Niigata
Koichi KOBAYASHI. NIIGATA University
Makoto SAKAMOTO. NIIGATA University
Takashi SATO. Niigata Kobari Hospital
Yoshio KOGA. Niigata Kobari Hospital

Key words: Biomechanics, Bone, Three-dimensional surface model, MRI, Accuracy

\section{1. 緒意}

X 線 CT や核磁気共鳴イメージング（MRI）に代表される 画像撮影装置は非侵襲的にヒトの体内構造を稓察できる有用 な手段であり、診断や治療などに広く使われている。近年、 画像診断装置の進歩により、得られた 2 次元断層画像から 3 次元形状モデルが構築でき、骨構造を 3 次元的に観察するこ とが可能になっている。整形外科分野において、骨の 3 次元 形状モデルは膫運動解析や術前計画、術後評価などに臨床応 用されており(1)、正確なモデルの使用は適切な診断や骨構造 の評価につながる。

骨の 3 次元形状モデルは一般的に CT で撮影された断層画 像を用いて構築されている。CT 海られる画像の寸法精度 が高く、比較的よく骨を描出することが可能であることから、 CT から構筑されたいわゆる CT 由来の 3 次元モデルは骨構 造がよく表現されている。その反面、CT は軟骨などの軟部 組織の描出ができない、放射線被爆量が多いといった問題が ある。関節部などの診断において、骨だけではなく軟骨も含 めたモデルが利用できれば、より容易に適切な診断が行える。

CT と同様な断層画像撮影装置の一つである MRI は CT で 指摘されるような問題点がなく、軟骨が描出できるため軟骨 を含む骨の 3 次元モデルの構筑が可能となる。しかし、軟骨 が描出される代わりに骨が描出できなくなり、骨の輪郭が不 明瞭になるため、骨の 3 次元形状モデルを構築する際に多大 な影響を与えると考えられる。現在のところ、MRIによる 3 次元モデルの精度についての報告は少ない。

そこで本研究は、CT 由来の骨の 3 次元形状モデル (CT モ デル）の代わりに、MRI 由来の軟骨を含む 3 次元形状モデル の臨床応用を検討することに先立ち、MRI 由来の骨の 3 次元 形状モデル（MRI モデル）の精度を検証することを目的とし た。

\section{2 実験方法}

2. 1 骨の 3 次元形状モデルの構築

対象としてブタ屍体後肢 3 肢を用いた。大腿骨と脛骨に MRI と CT の両方で描出できる球マーカーをそれぞれ 3つず つ取り付けた。球マーカーを取り付けたブタ後肢を MRI お よびCT で撮影した。撮影には MRI（MAGNETOM Impact Expert 1.0T, SIEMENS) および X 線 CT (X-Vigor Laudator, TOSHIBA Corp.) を用いた。MRI の撮影条件はスライス厚
$1.8 \mathrm{~mm}$ 、画面解像度 $512 \times 512$ pixels、ピクセルサイズ 0.59 $\times 0.59 \mathrm{~mm}$ 、撮像断面は矢状断面で、撮影シーケンスは軟骨 が強調される 3D-FLASHを用い、CTではスライス厚 $1.0 \mathrm{~mm}$ 、 画面解像度 $640 \times 512$ pixels、ピクセルサイズ $0.35 \times 0.35 \mathrm{~mm}$ 、 撮像断面は横断面であった。

MRI と CT 撮影で得られた断層スライス画像は、三次元再 構成ソフトウェア (ZedView ver. 4.0, LEXI Co.) を用いて骨 の 3 次元形状モデルを構筑した。このソフトウェアは 3 次元 形状モデル作成の際に柔軟に輸郭条件を設定でき、CT モデ ルでは骨輪郭を自動抽出したが、MRI モデルでは骨輪郭が自 動で抽出できなかったため、手動で輸郭抽出を行った。構筑 された MRI モデルと CT モデルを Fig. 1 に示す。

\section{2 モデルの精度検証方法}

3 次元モデルの精度検証は、(1)骨に取り付けた球マーカー 間の相対位置関係と、(2)骨断面の大きさについて、実際の骨

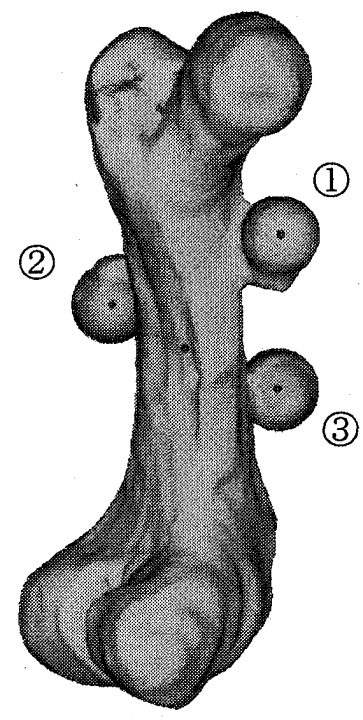

(a)

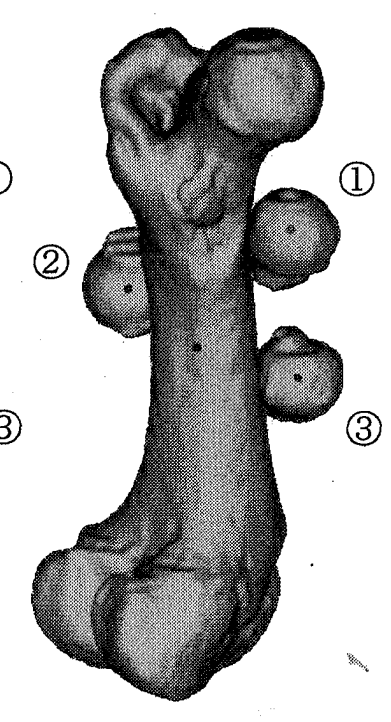

(b)
Fig. 1 MRI model (a) and CT model (b) 
での值（真値）と比較することで行った。

MRI、CT 摄影後、ブタ大腿骨と脛骨に創外固定器を取り 付けた。三次元測定器 (COORDINATE MEASURING MACHINE BH504, Mitutoyo Co.) で各球マーカーの 3 次元 的な位置を測定し、球マ一カーの中心座標を求め、球マ一カ 一間の 3 次元的な距離を算出した。これを相対位置の真值と した。取り付けた球マーカーは大腿骨近位から遠位へかけて (1)、(2)、(3)とした（Fig. 1)。構築された 3 次元モデルは各球 マーカーの中心座標を手動による球近似で求め、その中心座 標值から球マーカー間の相対位置（球マーカー(1)と(2)、(2)と (3)および(1)と(3)間の距離) を求め、相対位置の真值と比較し た。実際の骨寸法と比較するため、3 次元モデルの球マーカ 一が取り付けられた位置を骨幹に対し垂直にモデルを切断し、 その切断面の大きさ (縦と横) を計測した（Fig. 2)。計測さ れた值と骨断面の真値を比較した。

\section{3. 結果と考察}

Fig. 3 に MRI モデルと CT モデルの球マーカー間距離から 算出した断層平面方向と奥行き方向の真値に対する平均誤差 と標準偏差を示す。左から $\mathrm{x}$ 軸方向（断屬面の奥行き）、 $\mathrm{y}$ 軸 方向（断層面の横）、 $\mathrm{z}$ 軸方向 (断層面の縦) を示し、白が MRI モデル、黒が CT モデルを示す。真值に対して、MRI モデルでは $\mathrm{x}$ 軸方向に $0.27 \mathrm{~mm} 、 \mathrm{y}$ 軸方向に $0.18 \mathrm{~mm} 、 \mathrm{z}$ 軸 方向に $0.10 \mathrm{~mm}$ の誤差が見られた。CT モデルでは $\mathrm{x}$ 軸方向 に $0.05 \mathrm{~mm} 、 \mathrm{y}$ 軸方向に $0.02 \mathrm{~mm} 、 \mathrm{z}$ 軸方向に $0.18 \mathrm{~mm}$ の 誤差が見られた。MRI モデルは真俌よりも小さい傾向があり、 CT モデルはわずかに大きい傾向があったが、全体的に非常 に小さな誤差が得られた。したがって MRI、CT モデルはと もに相対位置においてはほぼ同程度の精度を有していると考 えられる。

3 次元モデルにおける骨断面の大きさについての結果を Fig. 4 に示し、MRI モデルと CT モデルにおける骨断面の縦 寸法と横寸法の真值に対する平均誤差と標準偏差を示す。左 から球マーカー(1)が取り付けられた骨断面の誤差、球マーカ 一(2)での骨断面の誤差、球マーカー(3)での誤差となり、白が MRI モデルの縦寸法、斜線が MRI モデルの横寸法を示し、 黒は CT モデルの縦寸法、横線が CT モデルの横寸法を表す。 真值に対して、MRI モデルでは球マーカー(3)の縦寸法で最大 $4.24 \mathrm{~mm} 、 \mathrm{CT}$ モデルは球マーカー(1)の縦寸法で最大 1.78 $\mathrm{mm}$ の誤差があった。CT モデルでは誤差が $2 \mathrm{~mm}$ 以下であ るものの、MRI モデルでは約 $4 \mathrm{~mm}$ の誤差があり、特に縦寸 法の誤差が大きくなっている。この原因として、MRI の撮像 断面が矢状断面であり、MR 画像の骨輪郭の不明瞭さが縦寸 法に大きく影響を与えることや、スライス厚が $1.8 \mathrm{~mm}$ とや や大きかったためと思われる。撮像断面を横断面にすれば、 骨断面の大きさへの影響は少ないが、代わりに関節面への影 響が大きくなると予想される。よって、MR 画像自体の精度 は良好であるが、モデル構築の際の骨輸郭抽出が誤差を大き くする原因と考えられ、骨翰郭抽出の改善により誤差を縮小 することが可能であると考える。

\section{4. 結言}

MRI を用いてブタ大腿骨の 3 次元形状モデルを構築し、実 際の骨との誤差を調べた。真值と比べると MRI モデルは、 球マーカ一間の相対位置関係においては良好な結果が得られ たが、骨断面に関しては矢状断面における骨輪郭抽出により 誤差が大きかうた。骨輪郭抽出の改善により誤差を縮小寸る ことが可能と考える。

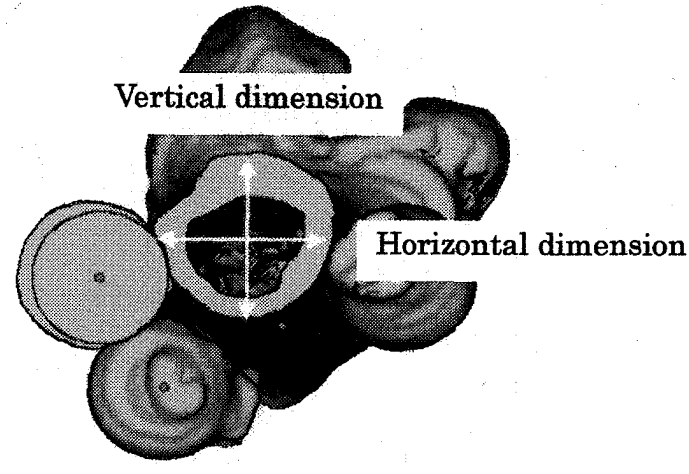

Fig. 2 Compared dimensions at cross-section of bone

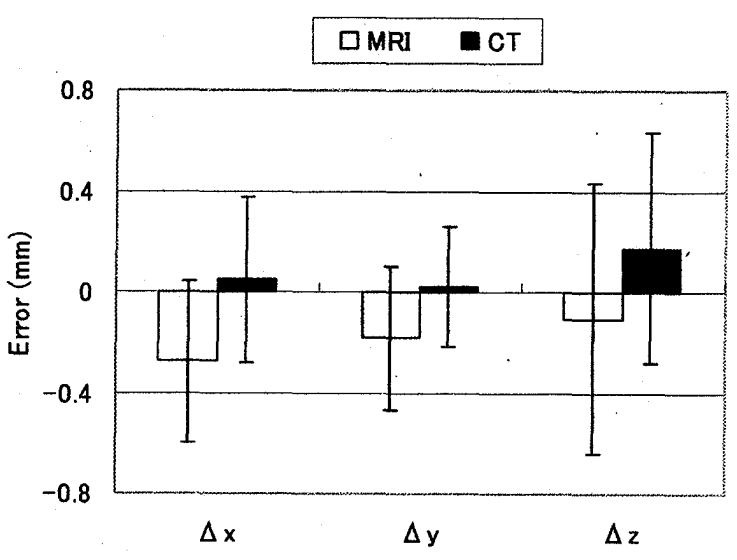

Fig. 3 Errors in distance between spherical markers.

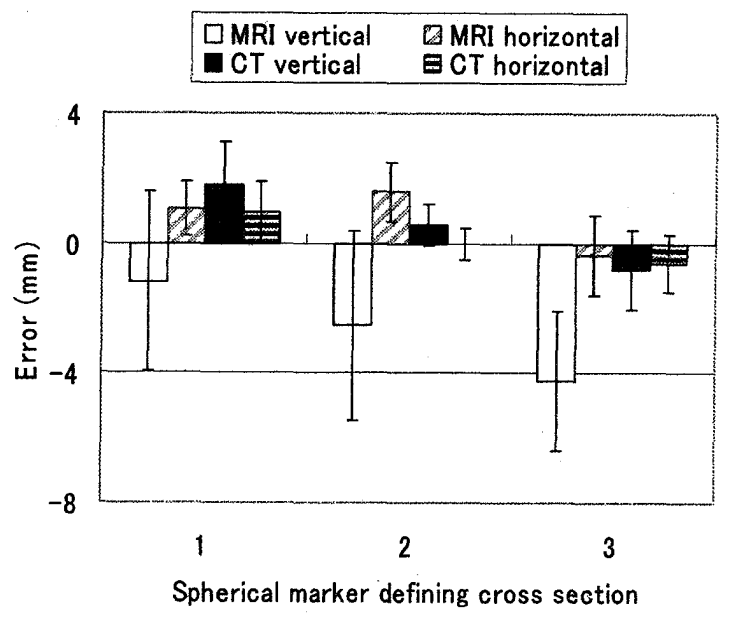

Fig. 4 Errors in dimensions of bone models.

5. 参考文献

（1）平澤、林、古賀、佐藤、松沢、中村、3 次元下肢アライ メント評価システムを用いた人工関節後の㮏関節運動 解析、日本臨床バイオメカニクス学会誌、Vol. 25、pp. 291-296、2004. 